\title{
Immunologie: het hart van de zaak
}

Citation for published version (APA):

Tervaert, J. W. (2001). Immunologie: het hart van de zaak. Maastricht University. https://doi.org/10.26481/spe.20010621jt

Document status and date:

Published: 21/06/2001

DOI:

10.26481/spe.20010621jt

Document Version:

Publisher's PDF, also known as Version of record

\section{Please check the document version of this publication:}

- A submitted manuscript is the version of the article upon submission and before peer-review. There can be important differences between the submitted version and the official published version of record.

People interested in the research are advised to contact the author for the final version of the publication, or visit the DOI to the publisher's website.

- The final author version and the galley proof are versions of the publication after peer review.

- The final published version features the final layout of the paper including the volume, issue and page numbers.

Link to publication

\footnotetext{
General rights rights.

- You may freely distribute the URL identifying the publication in the public portal. please follow below link for the End User Agreement:

www.umlib.nl/taverne-license

Take down policy

If you believe that this document breaches copyright please contact us at:

repository@maastrichtuniversity.nl

providing details and we will investigate your claim.
}

Copyright and moral rights for the publications made accessible in the public portal are retained by the authors and/or other copyright owners and it is a condition of accessing publications that users recognise and abide by the legal requirements associated with these

- Users may download and print one copy of any publication from the public portal for the purpose of private study or research.

- You may not further distribute the material or use it for any profit-making activity or commercial gain

If the publication is distributed under the terms of Article $25 \mathrm{fa}$ of the Dutch Copyright Act, indicated by the "Taverne" license above, 


\title{
Immunologie: het hart van de zaak
}

\author{
REDE \\ uitgesproken bij de aanvaarding van het ambt \\ van hoogleraar Interne Geneeskunde \\ in het bijzonder de Immunologie aan de \\ Faculteit der Geneeskunde \\ van de Universiteit Maastricht \\ op donderdag 21 juni 2001
}

door

Dr. Jan Willem Cohen Tervaert 
(C) J.W. Cohen Tervaert, Maastricht 2001

Vormgeving: Désirée Mesterom

Druk: Unigraphic 
Mijnheer de Recror Magnificus,

Zeer gewaardeerde toehoorders,

De immunologie is een prachtig vakgebied! Maar wat houdt het eigenlijk in?

Het vakgebied bestudeert het immunusysteem, een zeer geavanceerd verdedigingssysteem, dat zich kenmerkt door een uitzonderlijk vermogen om zich aan vrijwel iedere nieuwe vijand, meestal een micro-organisme of een kwaadaardige tumor, aan te passen. Helaas is het systeem niet $100 \%$ betrouwbaar en ziet het soms vijanden, die geen vijanden zijn zoals orgaantransplantaten, waardoor deze afgestoten worden, beschouwt het soms onderdelen van het eigen lichaam als vijand hetgeen resulteert in auto-immuunziekten als suikerziekte en reuma, of gebruikt het soms volkomen verkeerde wapens om de vijand te verslaan, hetgeen leidt tot allergie en astma.

Het woord immunologie is afgeleid van het Latijnse woord 'immunis'. In de tijd van het Romeinse Rijk werd dit woord gebruikt om personen aan te duiden die vanwege hun vele verdiensten of vanwege hun leeftijd 'immuun' waren geworden voor het betalen van belasting en dus in een zeer bevoorrechte situatie verkeerden dat zij zich niet hoefden te verstoppen voor belastinginspecteurs. De eerste, die het fenomeen immuniteit introduceerde in de geneeskunde was de historicus Thucydides. Ongeveer in 430 voor Christus beschreef hij een pestepidemie in Athene en merkte hij op dat de zieken alleen verpleegd konden worden door diegenen, die zelf hersteld waren van de pest en dientengevolge immuun waren geworden voor de ziekte.

Pas in 1890 ontdekten Von Behring en Kitasato dat deze immuniteit overgedragen kon worden via serum, het vocht wat overblijft nadat uit gestold bloed de cellen zijn 
verwijderd. Na een jarenlange controverse werd uiteindelijk pas in de vijftiger jaren bewezen, dat niet alleen serum verantwoordelijk is voor deze immuniteit, maar dat ook de witte bloedcellen essentieel zijn voor immuniteit. Nu weten we dat bepaalde witte bloedcellen, de zogenaamde lymfocyten, de immuniteit bepalen. De factoren in serum worden geproduceerd door $B$ lymfocyten, die na uitrijping plasmacellen worden, en deze factoren heten antistoffen. De witte bloedcellen die verantwoordelijk zijn voor de cellulaire immuniteit zijn de zogenaamde T lymfocyten.

\section{Wat doet de afdeling Immunologie in Maastricht?}

De immunologie in de dit jatar 25 jaar jonge Universiteit is zo' $n$ beetje de benjamin van de medische faculteit. In 1979 werd door mijn voorganger Prof. Van Breda Vriesman de capaciteitsgroep Immunologie geformeerd. De afdeling groeide gedurende de afgelopen 10 jaar aanzienlijk met name toen een aantal jaren geleden het ziekenhuislaboratorium Immunologie fuseerde met de universitaire capaciteitsgroep Immunologie. Thans werken in vaste dienst bij de afdeling twee internisten, vier immunologen met een medisch-biologische achtergrond, 14 analytische medewerkers en 3 secretaressen. Hoewel onze afdeling in de faculteit en in het ziekenhuis in Maastricht een zeer bescheiden plaats inneemt gaat het toch wel degelijk om een belangrijk, een interessant en vooral een zeer uitgebreid vakgebied.

Binnen het werkterrein van de Immunologie onderscheiden we drie onderdelen:

a. de basale immunologie

b. de medische immunologie

c. de klinische immunologie 
Het eerste onderdeel, de basale immunologie, is een fundamentele basiswetenschap waarbij we bestuderen hoe de verschillende afweercellen functioneren. Onze groep richt zich op een tweetal onderzoekslijnen: a. het ontstaan van hart- en vaatziekten en $b$. de tumorimmunologie. Op de eerste onderzoekslijn kom ik later terug. De tweede lijn is een samenwerking met de werkgroep

Hematologie/Oncologie. Onder leiding van Dr. Bos bestuderen we de mogelijkheid om middels vaccinatie tumoren te bestrijden. Met de verkregen kennis hopen we in de toekomst door manipulatie van het immuunsysteem kanker beter te bestrijden.

Het tweede onderdeel, de medische immunologie, is een laboratorium specialisme. Hier gaat het erom dat er met behulp van immunologische testen bij patiënten een juiste diagnose kan worden gesteld. Het gaat hier om verschillende soorten testen.

Allereerst immunologische bepalingen om zeer zeldzame stoornissen in de afweer op te sporen. Hierbij zijn vaak ingewikkelde testen nodig om de juiste diagnose te stellen. Ons laboratorium heeft hierbij dus een duidelijke regionale functie.

Daarnaast worden in ons laboratorium ook diagnostische testen gedaan om minder zeldzame aandoeningen te diagnosticeren zoals bijvoorbeeld rheumatoide arthritis. Bij deze ziekte bepalen we reumafactoren en antistoffen tegen citrulline om vast te stellen of een patiënt met klachten van de gewrichten wel of geen reuma heeft. Gedurende de laatste jaren is het belang van een goed immunologisch laboratorium extra duidelijk geworden. Bij een aantal aandoeningen zoals de ziekte van Wegener en SLE kan het beloop van de ziekte voorspeld worden door de hoogte van de spiegels van autoantistoffen op een zeer nauwkeurige manier te meten. 
Vooral bij ziekten die met verbeteringen en verergeringen gepaard gaan, kan men op deze manier vaak een verergering van de ziekte zien aankomen en tijdig een goede behandeling starten. Dit betekent dat het laboratorium een zeer hoge constante kwaliteit moet kunnen leveren. Onder leiding van Dr. Damoiseaux en de hoofdanalisten Van Rie en Austen zullen we proberen ons laboratorium binnen vijf jaar te laten certificeren.

Het derde onderdeel is de klinische immunologie; een deelspecialisme van de interne geneeskunde. Het vakgebied van de klinisch immunoloog is relatief nieuw en nog niet goed afgebakend. De klinisch immunoloog behandelt en begeleidt met name patiënten, die aan een gesystematiseerde auto-immunziekte ofwel aan een immuundeficiëntie leiden. Het betreft hier vrijwel altijd zeldzame ziekten. Concentratie van deze patiënten in een centrum is van groot belang. Niet alleen is het voor de patiënt belangrijk dat de arts specifieke kennis heeft van zijn of haar ziekte, ook zal de supergespecialiseerde specialist makkelijk collegae uit het eigen ziekenhuis of andere centra in Nederland of het buitenland benaderen als die meer ervaring hebben in de begeleiding van een onderdeel van deze ziekten. Meestal is er namelijk een multidisciplinaire aanpak nodig waarbij vele verschillende specialisten betrokken zijn. Daarnaast is er voor de meeste aandoeningen, die de klinisch immunoloog ziet, een nationale en/of internationale studiegroep, die klinische studies organiseert met als doel meer inzicht in het ontstaan van de ziekte te krijgen en de behandeling van de ziekte te optimaliseren. Helaas worden de patiënten en de onderzoekers op dit moment bedreigd door een voor het geneeskundig onderzoek nieuw gevaar: de bureaucratie! Wat is het geval? 
Klinische studies moeten goed gekeurd worden door commissies die kijken of de studies ethisch verantwoord zijn. Daarnaast kijken er tegenwoordig in ons ziekenhuis verschillende hoog opgeleide medewerkers naar de diverse studievoorstellen om te voorkomen dat de studies voor het ziekenhuis een financiële strop worden..... Het komt daarom op dit moment voor dat er meer dan 30 medewerkers zich buigen over studies waar op zijn hoogst vanuit Maastricht 5 patiënten geïncludeerd zullen worden. En dat is nog niet alles! We worden als onderzoekers ook nog eens geconfronteerd met hoge rekeningen voordat de studie van start kan gaan. Voor niet gesubsidieerd onderzoek is dit een echte ramp! Ik pleit er dan ook voor om dit proces efficiënter, sneller en goedkoper te laten verlopen. Met name voor zeldzame ziekten is dit een noodzaak, omdat dit soort studies vrijwel nooit door het bedrijfsleven gesponsord worden....

Als voorbeeld dat het ook efficiënter, goedkoper en sneller kan, wil ik de registratie van nieuwe geneesmiddelen bij zeldzame ziekten, zogenaamde orphan diseases, ten tonele voeren. Hierbij kunnen nieuwe geneesmiddelen op het ogenblik via een fast track in Europa en in de USA op uiterst efficiënte wijze, vaak binnen 3 maanden, geregistreerd worden.

Een mooi voorbeeld van concentratie van zeldzame ziekten is de Regionale Nierwerkgroep Limburg. Van alle patiënten uit de regio, bij wie een nierbiopsie wordt verricht, wordt het weefsel op een voortreffelijk gestandaardiseerde manier afgenomen en onderzocht. Hierdoor beschikt de nierwerkgroep over een unieke verzameling, waarmee belangrijk onderzoek gedaan kan worden. Zo snijden we met een door Dr. Heeringa opgezette techniek met behulp van een laserstraal ontstoken nierfilters uit nierbiopten. 
Vervolgens kunnen we dan bestuderen welke genen bij nierontsteking met name actief zijn.

Een andere belangrijke taak wan de klinisch immunoloog is het stimuleren van patiëntgerelateerd onderzoek. Hierbij is het essentieel dat klinische gegevens van patiënten met diverse ziekten volgens een gestandaardiseerde manier worden verzameld en dat het bloed van deze patiënten in het immunologisch laboratorium onderzocht wordt. Binnen de korte tijd dat ik nu in Maastricht ben is het gelukt om met een aantal groepen afspraken te maken. Ik wil hier het onderzoek naar diverse autoantistoffen bij colitis ulcerosa, de ziekte van Crohn en spruw met de afdelingen Gastro-enterologie en Kindergeneeskunde noemen, het onderzoek naar antistoffen tegen geoxideerd LDL bij niertransplantatiepatiënten met de afdeling Nefrologie, het onderzoek naar heat-shock-proteine 70 antistoffen bij patiênten met plotselinge doofheid met de afdeling $\mathrm{KNO}$, het onderzoek naar MPO polymorfisme bij sarcoïdose met de afdeling Longziekten, het onderzoek naar $\mathrm{T}$ cel regulatie en depressies bij patiënten met multipele sclerose met de afdelingen Neurologie en Psychiatrie et cetera et cetera.

Mijne Dames en Heren, het moge duidelijk zijn; er is genoeg te doen!

\section{Onderwijs}

Naast het uitvoeren van bovengenoemde taken is het ook belangrijk om de opgedane kennis uit te dragen zowel naar collegae specialisten, arts-assistenten, analisten, promovendi als naar studenten. Niet alleen studenten Geneeskunde ook de studenten van de Faculteit der Gezondheidswetenschappen dienen onderwijs in de Immunologie te krijgen. En hier is iets zeer merkwaardigs aan de hand.... 
Terwijl de universiteit massaal inzet op Moleculaire Biologie en Moleculaire Genetica lijken de Immunologie en dan met name de Moleculaire Immunologie in Maastricht tot voor kort aan de aandacht ontsnapt te zijn. De Faculteit der Gezondheidswetenschappen heeft zelfs geen enkele immunoloog bij onze afdeling gestationeerd... een unicum in Nederland! Om het immunologisch onderwijs toch zo adequaat mogelijk te doen en goed met elkaar af te stemmen, hebben we in overleg met Prof. Scherpbier besloten een onderwijs werkgroep Immunologie op te richten. Deze werkgroep staat onder leiding van Dr. Duijvestijn en aan deze werkgroep doen ook immunologen werkzaam bij andere afdelingen mee, zoals Prof. Buurman en Dr. De Baets.

Tot zover de uitleg wat Immunologie in Maastricht inhoudt.

Deze oratie heeft als titel meegekregen: Immunologie: het hart van de zaak.

Hiermee heb ik willen aangeven dat de Immunologie een centrale rol speelt bij vrijwel alle ziekten. Daarnaast wil ik met deze titel nog iets heel anders aangeven...

De hoofdlijn van het onderzoek, waar onze groep zich de komende jaren op wil richten is de rol die immunologische factoren spelen bij het ontstaan van harten vaatziekten.

En de plannen omtrent het onderzoek bij één van deze ziekten, namelijk atherosclerose, wil ik vandaag bespreken.

\section{Atherosclerose is een ontstekingsziekte}

Atherosclerose of ook wel aderverkalking is de ziekte, die meestal verantwoordelijk is voor een hartaanval of een herseninfarct. Daarnaast speelt de ziekte een belangrijke rol bij het ontstaan van etalagebenen, nierfalen en 
dementie. De ziekte wordt gekenmerkt door een verharding en vernauwing van slagaderen, waarbij op het oppervlak van de vaten heel snell stolselvorming kan ontstaan. Al jaren lang is bekend, dat het hebben van een hoog cholesterolgehalte, hoge bloeddruk, suikerziekte of het familiair voorkomen van de ziekte risicofactoren zijn voor het krijgen van complicaties van atherosclerose. Afwijkingen in de bloedvaten als teken van beginnende atherosclerose zijn bij de meeste mensen al op kinderleeftijd aanwezig. Toch treden de symptomen zoals bijvoorbeeld een hartaanval meestal pas na het $55^{\text {sle }}$ levensjaar op.

Gedurende de laatste 5 jaar is vooral door het werk van Paul Ridker uit het Brigham and Women's Hospital in Boston gebleken dat met de bepaling van ontstekingseiwitten in het bloed voorspeld kan worden wie een hart- of herseninfarct krijgt in de toekomst. Hierbij mat hij het C-reactieve proteine, een stofje, waarvan we al jaren weten, dat deze verhoogd in het bloed aanwezig is, als de patiënt een ontsteking doormaakt. Geheel tegen de gangbare verwachting in bleek dit stofje veel beter dan het cholesterolgehalte te voorspellen wie de meeste kans maakt op het krijgen van een infarct.

Een belangrijke vraag is nu: waar komt deze ontsteking vandaan?

De meest gangbare hypothese is dat deze ontsteking veroorzaakt wordt door geoxideerd LDL cholesterol. Hiervan is immers bekend dat het ontstekingscellen kan activeren. Ik vermoed echter dat de ontsteking voor een belangrijk gedeelte een immunologische ontsteking is en dat atherosclerose in feite een auto-immuunziekte is net 
als reuma, suikerziekte en multipele sclerose. Hoe ik hierbij kom zal ik proberen uit te leggen.

We denken dat het proces van atherosclerose via verschillende mechanismen kan starten. Eén van de belangrijkste is dat door oxidatie van het zogenaamde 'slechte cholesterol', het LDL cholesterol, geoxideerd LDL cholesterol ontstaat. Dit geoxideerde LDL cholesterol prikkelt de binnenste bekleding van bloedvaten zodanig dat zij meer doorgankelijk voor cholesterol wordt. Bovendien zorgt het geoxideerde LDL ervoor dat circulerende witte bloedcellen zich aan de vaatwand kunnen gaan hechten.

Welke circulerende witte bloedcellen zijn dat?

De cellen, die bij atherosclerose aan de vaatwand hechten, zijn vooral monocyten en lymfocyten. De meeste aandacht hebben de monocyten de afgelopen jaren gekregen. Deze penetreren de vaatwand en veranderen in macrofagen. De normale functie van macrofagen is dat ze op zoek gaan naar bacteriën en deze als het ware verslinden. Bij atherosclerose gaan ze echter cholesterol stapelen, waardoor er vetrijke kernen, zogenaamde fatty streaks, ontstaan. Op de vaatwand kunnen nu stolsels ontstaan, waarna er uiteindelijk een beschermende fibreuze kap gevormd wordt. Deze zogenaamde fibreuze plaques kunnen ruptureren en losschieten met als gevolg een hartaanval of therseninfarct.

De ontstekingseiwitten, die bij patiënten met atherosclerose in het bloed gevonden worden en die een voorspellende waarde hebben voor het optreden van een infarct worden vooral door de macrofagen geproduceerd. Macrofagen maken als ze geactiveerd zijn Neopterine, een uniek stofje dat in het bloed gemeten kan worden. Neopterine waarden zijn significant hoger bij patiënten 
met halsslagaders, die tekenen van aderverkalking vertonen dan bij mensen waarbij de halsslagader geen tekenen van aderverkalking vertoont. Paul van Haelst, promovendus in Groningen, bepaalde de Neopterine spiegels bij patiënten, die met chollesterol verlagende medicijnen behandeld werden en vond dat tijdens deze behandeling diverse merkers van ontsteking waaronder het Neopterine daalden. De resultaten van deze studie passen bij de thans populaire hypothese dat de nieuwe cholesterolverlagende middelen, ook wel statines genoemd, hun gunstig effect op hart- en vaatziekten voor een belangrijk deel te danken hebben aan een direct ontstekingsremmend effect van deze geneesmiddelen.

\section{Atherosclerose is een immunologische aandoening}

De bevinding dat atherosclerose in feite een ontsteking van bloedvaten is, plaatst deze ziekte dichtbij de andere ziekten, waarbij de bloedvaten ontstoken zijn, de zogenaamde vasculitiden.

Met studies naar het ontstaan van deze ziekten heb ik me de laatste jaren vooral beziggehouden en het hiermee verkregen inzicht wil ik de komende jaren toepassen op atherosclerose.

De volgende vraag bij het ontstaan van atherosclerose is: hoe worden de macrofagen geactiveerd? Al jaren weten we dat activatie van macrofagen nodig is om intracellulaire bacterièn te doden en dat deze activatie geschied door een stofje dat interferon gamma heet. Al 15 jaar geleden werd gevonden dat interferon gamma producerende cellen tot $20 \%$ van de cellen van de atherosclerotische plaque kunnen uitmaken en dat deze cellen tot de allereerste cellen behoren, die de vaatwand infiltreren bij atherosclerose. 
Er zijn verschillende soorten witte bloedcellen, die interferon gamma kunnen maken. Dit zijn de T helper 1 cellen, de cytotoxische $T$ cellen en de Natural Killer cellen.

De productie van interferon gamma is zeer belangrijk voor het overwinnen van diverse infecties. Daarnaast heeft interferon gamma ook een belangrijke regulerende functie. Dit stofje wordt bijvoorbeeld ook in verband gebracht met de toename van allergische aandoeningen bij jonge kinderen. Een populaire hypothese is dat jonge kinderen in een te beschermde wereld leven, te weinig virusinfecties doormaken, te weinig interferon gamma maken en daarom een immuunsysteem hebben die de neiging heeft om allergisch te reageren.

Wat is er bekend over de cellen, die bij atherosclerose interferon gamma produceren?

Verschillende groepen hebben de $\mathrm{T}$ cellen, die in de door aderverkalking aangetaste vaten zitten bestudeerd. In het verleden was de gedachte populair dat deze $\mathrm{T}$ cellen onbedoeld in de laesie terecht zijn gekomen, alsof ze als het ware in de laesies ingevangen waren en vervolgens hier niet meer uit weg konden komen.

Analyse van de cellen in de laesies leverde echter op, dat de cellen verschillen van de in het bloed circulerende $T$ cellen. Dit maakt de hypothese dat ze per ongeluk in de laesie terechtgekomen zijn onwaarschijnlijk. Het bleek bijvoorbeeld dat de cellen in de laesies tekenen van cel activatie vertonen, aangezien ze positief aankleuren voor de activatiemerker HLA-DR. Dit alles wijst erop dat de T cellen niet zo maar in de laesies gevangen worden, maar dat ze mogelijk door een specifieke stimulus daar naar toe aangetrokken zijn. Inderdaad kan in muizen, die snel atherosclerose ontwikkelen, omdat ze het apoE gen 
missen en daardoor een erg hoog cholesterol gehalte in het bloed hebben, aangetoond worden dat de respons van de $T$ cellen in de laesies slechts tegen een beperkt aantal antigenen gericht is. In dle immunologie noemen we dat oligoclonaal.

In muizen lijkt het er dus op dat er specifieke stimuli zijn die de T cellen aantrekken. Hoe zit dat bij mensen? Recente studies van onderzoekers uit de Mayo Clinic suggereren dat $\mathrm{T}$ cellen uit laesies van patiënten met instabiele atherosclerose slechts een beperkt aantal antigenen herkennen.

Zij vonden dat de $T$ cellen in de laesies een oligoclonale respons vertoonden, die overeenkwam met een oligoclonale respons, die bij bepaalde circulerende $\mathrm{T}$ cellen werd teruggevonden. Deze $\mathbb{T}$ cellen zijn in verhoogde mate in de circulatie aantoonbaar bij patiënten met instabiele atherosclerose. $\mathrm{Zij}$ behoren tot een nieuw type $\mathrm{T}$ cellen, hebben kenmerken van zowel $\mathrm{T}$ helper 1 cellen, cytotoxische T cellen en NK cellen, prolifereren langzaam en kunnen via productie van het eerder genoemde interferon gamma heel makkelijk ontsteking op gang brengen. Deze interessante cel verschilt van alle andere $\mathrm{T}$ cellen, aangezien ze jarenlang functioneel actief kunnen blijven omdat ze een defect vertonen in het geprogrammeerde celdoodsysteem. Het is een celtype dat vrijwel nooit bij gezonde mensen onder de 40 gevonden wordt. Hun aantal kan echter sterk toegenomen zijn bij ouderen en met name bij chronische ontstekingen, zoals bijvoorbeeld reuma, een ziekte, die zeer frequent door bloedvatontsteking en atherosclerose wordt gecompliceerd. 


\section{Is atherosclerose een infectieziekte of een auto- immuunziekte?}

Spelen die T cellen ook een causale rol? Met andere woorden veroorzaken ze het hart- en/of herseninfarct?

Een dergelijke vraagstelling is momenteel niet te beantwoorden omdat het perfecte diermodel voor instabiele atherosclerose nog ontbreekt. Wel zijn er diermodellen die ons kunnen helpen. Hier wordi dan meestal gebruik gemaakt van muizen, die versneld atherosclerose krijgen zoals de eerder genoemde ApoE deficiënte muis. Als deze muis gekruist wordt met een muis, die geen interferon gamma kan maken, hebben de nakomelingen wan dit echtpaar $60 \%$ minder atherosclerotische laesies dan de ApoE familieleden. Ook kunnen de ApoE muizen met muizen gekruist worden, die geen $\mathrm{T}$ cellen en geen $\mathrm{B}$ cellen hebben. Deze ApoE muizen, die met zogenaamde SCID muizen gekruist zijn, krijgen nakomelingen die zelfs $70 \%$ minder laesies hebben. Als deze muizen vervolgens $T$ cellen van de atherosclerotische ApoE muis ingespoten krijgen, krijgen deze muizen wel een ernstige atherosclerose.

Al deze gegevens leren ons dat atherosclerose een ziekte is, waar het immuunsysteem nauw bij betrokken is. Met name bij instabiele atherosclerose, dwz. bij patiënten met een hartaanval of een herseninfarct, is er sprake van een belangrijke immunologische ontsteking. We hebben gezien dat Neopterine, een product van geactiveerde macrofagen verhoogd in het bloed aantoonbaar is; dat de activatie van macrofagen een gevolg is van interferon gamma en dat deze interferon gamma mogelijk afkomstig is van hele specifieke $\mathrm{T}$ cellen, die slechts een beperkt aantal antigenen herkennen. 
Dit suggereert dat $\mathrm{T}$ cellen niet alleen in de laesies aanwezig zijn maar ook een belangrijke rol spelen bij het ontstaan van atherosclerose.

De hamvraag is nu: wat zijn de antigenen die herkend worden door de $\mathrm{T}$ cel?

Antigenen zijn de substanties, die een afweerrespons kunnen uitlokken.

Antigenen, die een T cel respons uitlokken worden eerst door zogenaamde APCs, dwz antigeen presenterende cellen klaargemaakt voordat ze door $\mathrm{T}$ cellen herkend worden. Deze APCs bevinden zich op strategische plaatsen in het lichaam om indringers op te pikken zoals bijvoorbeeld in de huid en in de bloedvaten.

Antigenen zijn meestal eiwitten of suikerketens. Een enkele keer kunnen ook vetten als antigeen werken. Antigenen kunnen niet alleen afkomstig zijn van microorganismen, ook herkent het immuunsysteem lichaamseigen antigenen of wel autoantigenen. Gelukkig worden de cellen, die autoantigenen herkennen goed onder controle gehouden via allerlei regulatiemechanismen. Bij auto-immuunziekten schiet de regulatie tekort en kunnen deze autoantigeen herkennende cellen gaan prolifereren en aanleiding geven tot een autoimmuunziekte.

Over de antigenen, die bij atherosclerose herkend worden is nog erg weinig bekend. Onze groep wil dit in de komende jaren intensief gaan bestuderen. De afgelopen tijd ging vooral veel aandacht uit naar antigenen van micro-organismen, zoals $U$ in vele kranten hebt kunnen lezen. Dit komt omdat bij sommige patiënten met antibiotica het risico van complicaties van atheroselerose verminderd kan worden. Vooral luchtweginfecties en 
tandvleesontstekingen worden genoemd als risicofactor voor atherosclerose. Micro-organismen, die met name genoemd worden zijn chlamydia pneumoniae, cytomegalovirus en helicobacter pylori. Er is op dit moment echter nog weinig bewijs dat de immuunrespons bij atherosclerose daadwerkelijk gericht is tegen een micro-organisme.

Ik vind het veel waarschijnlijker dat de immuunrespons gericht is tegen lichaamseigen antigenen en dat atherosclerose dus waarschijnlijk een auto-immuunziekte is.

Ook hier is er een aantal kandidaten.

Allereerst kan LDL cholesterol na oxidatie een immuunrespons op gang brengen.

Een tweede autoantigeen is een stress proteine, het zogenaamde heat shock proteine-60. Deze heat shock proteïnen (HSP) komen in alle cellen voor en spelen een bellangrijke rol bij het vouwen en intracellulaire transport van eiwitten. Onder stress krijgen ze nog een belangrijke functie: ze worden de chaperonne van eiwitten en beschermen in die situatie de intracellulaire eiwitten tegen beschadiging. HSPs komen na diverse stimuli op endotheelcellen, de binnenste bekleding van de bloedvaten, tot expressie. Stress stimuli, die de HSP expressie op endotheelcellen uitlokken, zijn bijvoorbeeld hitte, mechanische stress in het kader van hoge bloeddruk, infecties en geoxideerd LDL.

Samenvattend zijn er dus sterke aanwijzingen dat de immuunrespons een belangrijke rol speelt bij het ontstaan van atherosclerose. Of de immuunrespons gericht is tegen een micro-organisme of dat er sprake is van een autoimmuunziekte zal nader onderzoek moeten uitwijzen. Het idee dat aderverkalking louter een ziekte is die ontstaat 
door te veel roken, te vet eten en te weinig lichaamsbeweging lijkt achterhaald. Hoewel het bestrijden van deze risicofactoren voorlopig erg belangrijk blijft, wil onze groep de fundamentele vragen, die nog openstaan aangaande de rol van de immunologie bij deze fascinerende ziekte, proberen te beantwoorden. Hierbij zullen wij steeds patiëntenstudies proberen te combineren met laboratoriumstudies en studies waarbij we gebruik maken van muizen, die atherosclerose krijgen.

\section{Hoe ontstaan auto-immuunziekten?}

In de geplande studies hopen we niet alleen meer te weten te komen over de antigenen, die de $\mathrm{T}$ cellen stimuleren. Ook hopen we iets te leren waarom een eventuele autoimmuunreactie ontstaat. De gangbare hypothese over het ontstaan van andere auto-immuunziekten is dat er meerder factoren tegelijkertijd aanwezig moeten zijn (de zogenaamde 'bad-luck-hypothesis'). Hierbij denken we dan altijd aan een combinatie van erfelijke aanleg, schadelijke invloeden uit de omgeving, zoals bijvoorbeeld roken, en infecties. Met name de genetische factoren zullen de komende jaren veel aandacht krijgen. $Z o$ is er in Nature van 31 mei 2001 te lezen dat er bij een andere auto-immuunziekte, de ziekte van Crohn, een mutatie in het Nod-2 gen ontdekt is bij $20 \%$ van de patiënten. Hierdoor worden bacteriën minder efficiënt gedood met als gevolg een compensatoir sterkere reactie van het immuunsysteem. Een ander vergelijkbaar gen, het myeloperoxidase, wordt momenteel door onze groep intensief bestudeerd. Dit gen zorgt ervoor dat in ontstekingscellen hypochloriet gemaakt kan worden hetgeen heel belangrijk is voor het doden van bacteriën, zoals we ook in het dagelijks leven ervaren als we met Glorix of andere hypochloriet bevattende schoonmaakmiddelen werken. 
Onze hypothese is dat bij onvoldoende myeloperoxidase in de cellen bacteriën minder goed gedood kunnen worden en dat de compensatoire immuunreactie nadelig kan zijn voor ontwikkeling van auto-immuunziekten.

Met het verkregen inzicht hopen we uiteindelijk ook nieuwe behandelingsmethoden te introduceren. Hierbij valt te denken aan therapie, die gericht is op het beïnvloeden van $T$ cellen, zodat de hoeveelheid interferon gamma productie in de laesie af kan nemen. Wij willen bijvoorbeeld de effecten van blokkade van de CD40 - CD154 interactie bestuderen als mogelijk middel om de locale interferon productie te remmen. Een andere aanpak is het versterken van de regulatie van $T$ cellen. Hierbij valt bijvoorbeeld te denken aan simpele maatregelen als behandeling met ultraviolet $B$ licht, waarvan is aangetoond dat het de T helper 1 cellen kan remmen. Tenslotte is het ook mogelijk om de atherosclerotische $\mathrm{T}$ cellen te onderdrukken door orale tolerantie op te wekken. Zo blijkt het in proefdieren mogelijk om de immuunreactie af te zwakken door de voor de ziekte verantwoordelijke antigenen via voedsel aan de proefdieren toe te dienen. Hierdoor worden regulerende $T$ cellen gestimuleerd die vervolgens de $T$ helper 1 cellen in bedwang houden. Met zo'n nieuwe aanpak hopen we volksvijand nummer 1 een flinke slag toe te brengen!

\section{Slot}

Onvoldoende aandacht voor het immuunsysteem vormt mijns inziens een belangrijke beperking voor het begrip hoe ziekten ontstaan. Mede hierdoor zijn grote doorbraken met betrekking tot bijvoorbeeld de genezing van hart- en vaatziekten en kanker de laatste jaren uitgebleven. Het is mijn stellige overtuiging dat we in de 
toekomst door manipulatie van het afweersysteem nieuwe meer succesvolle therapieèn kunnen ontwikkelen.

Hiervoor is een zeer intensieve interactie tussen clinici en basaal-wetenschappelijke onderzoekers nodig. En hier is naar mijn idee nog heel wat te verbeteren in Maastricht! Plannen in deze richting worden op dit moment binnen de Interne Geneeskunde voorbereid om de beste studenten al vroeg in hun opleiding te betrekken bij het wetenschappelijk onderzoek in de Interne Geneeskunde. Door de enorme ontwikkeling binnen de moleculaire biologie en genetica dreigt namelijk de afstand tot de dagelijkse patiëntenzorg te groot te worden. Als docenten moeten wij ons dan ook tot taak stellen dat we onze studenten en assistenten enthousiasmeren om tijdens hun opleiding zelfstandig een stuk wetenschappelijk

onderzoek te verrichten. Want Dames en Heren, studenten en promovendi, $\mathrm{u}$ bent het die het werkelijk vernieuwende onderzoek mogelijk moet gaan maken! 


\section{Dankwoord}

Aan het einde van mijn rede wil ik graag een aantal mensen bedanken voor hun steun.

Mijnheer de rector magnificus, leden van het College van Bestuur en de Decaan van de Faculteit der Geneeskunde van de Universiteit Maastricht wil ik hartelijk bedanken voor het in mij gestelde vertrouwen. De voortvarendheid waarmee U samen met het bestuur van de Universiteit van Limburg te Diepenbeek (B) te werk gaat bij het opzetten van de studierichting Life Sciences aan de Transnationale Universiteit van Limburg maakt diepe indruk op mij. Ik waardeer het bijzonder dat ik in de gelegenheid ben gesteld om aan de totstandkoming van deze nieuwe studierichting mee te mogen werken.

De Raad van Bestuur van het azM dank ik voor de genereuze steun aan de afdeling Immunologie. Deze geeft ons de mogelijkheid een centrum op te bouwen waar de immunologische laboratoriumdiagnostiek op het allerhoogste niveau gebracht kan worden. Daarnaast stelt deze steun ons in staat om de patiëntenzorg op het gebied van de Klinische Immunologie en de Nierziekten voor de regio verder te verbeteren.

De hooggeleerde Heer Hillen, beste Harry. Jij bent de drijvende kracht van de afdeling Interne Geneeskunde. Je hebt mij de ruimte gegeven om de Immunologie en het immunologisch onderzoek een belangrijke plaats te laten krijgen binnen de Interne.

Hooggeleerde Mevrouw van Dieijen, beste Maria. Jou wil ik danken voor de bijzonder plezierige wijze waarop je mij wegwijs hebt gemaakt binnen de Eenheid Laboratoria en Klinische Farmacie. 
Hooggeleerde Heren Struijker Boudier en de Haan, beste Harry en Jelte. Jullie dank ik voor de ondersteuning, die ik van de onderzoeksinstituten CARTM en GROW krijg om het meer basale wetenschappelijk onderzoek van de afdeling Immunologie te versterken.

Mijn voorganger, de Hooggeleerde Heer van Breda Vriesman, beste Peter. Jou dank ik voor je hulp bij het verrichten van al het werk dat op mij afkomt als jong benoemde hoogleraar. Duizendpoten zoals jij zijn zeldzaam! Ik hoop dat we je met name voor de beoordeling van nierbiopten nog lang mogen inhuren. De heren Duijvestijn, Damoiseaux en Heeringa, beste Adriaan, Jan, en Peter. Jullie dank ik voor het scheppen van een zeer stimulerend werkklimaat binnen onze afdeling en voor het enthousiasme dat jullie aan de dag leggen wanneer er onderwijs gegeven wordt.

De hoofdanalisten, de heren van Rie en Austen, beste Henk en Jos. Jullie dank ik voor jullie inzet en bereidheid om heel veel werk uit mijn handen te nemen.

De steun van de medewerksters van het secretariaat Désiree, Anita en Petra is meer dan onmisbaar. Ook al moeten we al meer dan een jaar op aansluiting op het ZIS wachten toch blijven we positief dat het ooit nog eens goed komt!

De medewerk(st)ers Bram, Chris, Claire, Ellen, Harry, Heinz, Joyce, José, Luciënne, Maria, Marie-Paule, Marjan, Mia, Peter, Ruud, Silvie, Toos en Yvon dank ik voor hun toewijding, enthousiasme en inzet waarmee zij hun werk doen. Met jullie heb ik er alle vertrouwen in dat we de opgestelde plannen kunnen verwezenlijken! 
In mijn nieuwe werkkring werk ik op een bijzonder plezierige manier met velen samen. Ik kan niet allen bedanken en wil daarom slechts een tweetal groepen eruit lichten.

Allereerst het atherosclerose clubje. De Hooggeleerde Daemen, Bruggeman en Hofker, beste Mat, Cathrien en Marten. Het is een feest om als jong benoemde hoogleraar met zoveel deskundigheid uit verschillende capaciteitsgroepen samen te werken!

Ten tweede mijn collegae van de Interne Geneeskunde.

De plezierige samenwerking en vanzelfsprekende collegialiteil zorgen voor een aangename werksfeer.

Laten we dit vooral zo houden!

Nooit was ik in de gelegenheid gesteld om deze oratie te houden als ik niet in Groningen en in Boston mijn opleiding tot internist, nefroloog, klinisch immunoloog en wetenschapper had gehad. Hooggeleerde Mandema, Hooggeleerde Reitsma, Hooggeleerde van der Hem, en Hooggeleerde de Jong. $U$ hebt mij niet alleen de interne geneeskunde en de nefrologie geleerd, $U$ hebt mij ook de ruimte gegeven om naast mijn opleiding veel tijd te besteden aan patiëntgebonden wetenschappelijk onderzoek.

Tijdens mijn promotieonderzoek heb ik in de afdeling Klinische Immunologie van Prof. The kennis gemaakt met de diverse aspecten van de immunologie. Beste Hauw, de bijzonder persoonlijke manier waarop jij de afdeling organiseerde en toesprak zal altijd voor mij een voorbeeldfunctie hebben. Ik ben je dankbaar dat je mij de kans hebt gegeven om binnen je afdeling te promoveren en later te werken. 
De Nierstichting Nederland wil ik bedanken, dat ze mijn verblijf in Boston hebben willen financieren en mij ook na dit verblijf altijd in ruime mate zijn blijven sponsoren. Ik wil Prof. Gimbrone van Harvard Medical School bedanken voor de gelegenheid die hij mij geboden heeft om binnen zijn topafdeling te mogen werken. De Koninklijke Nederlandse Akademie van Wetenschappen wil ik bedanken voor het vertrouwen dat ze in mij gesteld hebben om mij gedurende 5 jaar te steunen om mijn onderzoek in Groningen voort te zetten.

Klinisch immunologisch onderzoek is een teamsport. Met Prof. Kallenberg, Dr. Limburg en Dr. Stegeman heb ik de laatste 7 jaar in Groningen in het team gezeten. Cees Kallenberg was onze libero; was altijd overal en had altijd energie voor tien; Piet Limburg was onze man in de goal; niet te passeren en bovendien degene die bij een blessure altijd met een enorme dosis humor de mannen weer snel op de been kreeg en Coen Stegeman was onze zeer getalenteerde spits; scoren kan hij als de beste, en daarnaast is hij buiten het veld ook een geweldige collega!

Maar het team bestond uit nog talloze anderen: de analisten, waarbij ik met name Minke Huitema wil noemen, de promovendi en studenten en bovendien was er onze captain, Kiki Bugter. Als secretaresse regelde jij de afdeling op een voortreffelijke wijze. Teamgenoten, ik ben er trots op dat ik bij jullie in het team zat en ik dank jullie voor jullie bijdrage.

Ik stel het bijzonder op prijs dat mijn schoonouders hier vandaag aanwezig kunnen zijn om deze feestelijke dag met mij door te brengen. Familie, schoonfamilie, Billies, en andere vrienden. Ik ben blij dat jullie hier aanwezig zijn; jullie zijn voor mij belangrijk. 
Mijn broer, Dirk, wil ik met name bedanken voor zijn continue support vooral na het overlijiden van onze ouders.

Mijn laatste woorden zijn voor Marretje, Thijs, Floor, Joost en Paul. De wissel op ons gezinsleven is de afgelopen tijd door mijn vertrek naar het verre Maastricht groot geweest. Ik mis jullie, want het is ongezellig om elkaar zo weinig te zien. Het gezinsleven is een continu bedrijf en het was dan ook even puzzelen om een goede dag te kiezen voor deze oratie. Maar we zijn eruit gekomen; de langste dag van het jaar.. wel krijgt Thijs morgen zijn diploma van het Gymnasium en zit Floor nog midden in haar proefwerkweek. Lieve kinderen en Marretje, ik dank jullie voor jullie geduld en liefde. 


\section{Bronnen}

- Brennan ML, Anderson MM, Shih DM, et al. Increased atherosclerosis in myeloperoxidase-deficient mice. J Clin Invest 2001; 107:419-30.

- Caligiuri G, Paulsson G, Nicoletti A, Maseri A, Hansson GK. Evidence for antigen-driven T-cell response in unstable angina. Circulation 2000; 102:1114-9.

- Glass CK, Witztum JL. Atherosclerosis: the road ahead. Cell 2001; 104:503-16.

- Hugot JP, Chamaillard M, Zouali H, et al. Association of NOD2 leucine-rich repeat variants with susceptibility to Crohn's disease. Nature 2001; 411:599-603.

- Kearney JF. Immune recognition of OxLDL in atherosclerosis. J Clin Invest 2000; 105:1683-5.

- Liuzzo G, Goronzy JJ, Yang H, et al. Monoclonal T-cell proliferation and plaque instability in acute coronary syndromes. Circulation 2000; 101:2883-8.

- Mayr M, Metzler B, Kiechl S, et al. Endothelial cytotoxicity mediated by serum antibodies to heat shock proteins of Escherichia coli and Chlamydia pneumoniae: immune reactions to heat shock proteins as a possible link between infection and atherosclerosis. Circulation 1999; 99:1560-6.

- Melian A, Geng YJ, Sukhova GK, Libby P, Porcelli SA. CD1 expression in human atherosclerosis. A

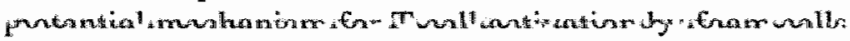
Am J Pathol 1999; 155:775-86.

- Ogura Y, Bonen DK, Inohara N, et al. A frameshift mutation in NOD2 associated with susceptibility to Crohn's disease. Nature 2001; 411:603-6. 
- Paulsson G, Zhou X, Tornquist E, Hansson GK. Oligocional $T$ cell expansions in atherosclerotic lesions of apolipoprotein E-deficient mice. Arterioscler Thromb Vasc Biol 2000; 20:10-7.

- Ridker PM. High-sensitivity C-reactive protein: potential adjunct for global risk assessment in the primary prevention of cardiovascular disease.

Circulation 2001; 103:1813-8.

- Schirmer M, Vallejo AN, Weyand CM, Goronzy JJ. Resistance to apoptosis and elevated expression of $\mathrm{Bcl}-$ 2 in clonally expanded CD4+CD28- T cells from rheumatoid arthritis patients. J Immunol 1998; 161:1018-25.

- Warrington KJ, Takemura S, Goronzy JJ, Weyand CM. CD4+,CD28- $T$ cells in rheumatoid arthritis patients combine features of the innate and adaptive immune systems. Arthritis Rheum 2001; 44:13-20.

- Zhou X, Nicoletti A, Elhage R, Hansson GK. Transfer of $\mathrm{CD} 4(+) \mathrm{T}$ cells aggravates atherosclerosis in immunodeficient apolipoprotein $\mathrm{E}$ knockout mice. Circulation 2000; 102:2919-22. 
